\title{
AUGUST-SEPTEMBER 1977
}

SEVENTEENTH YEAR - No. 197-198
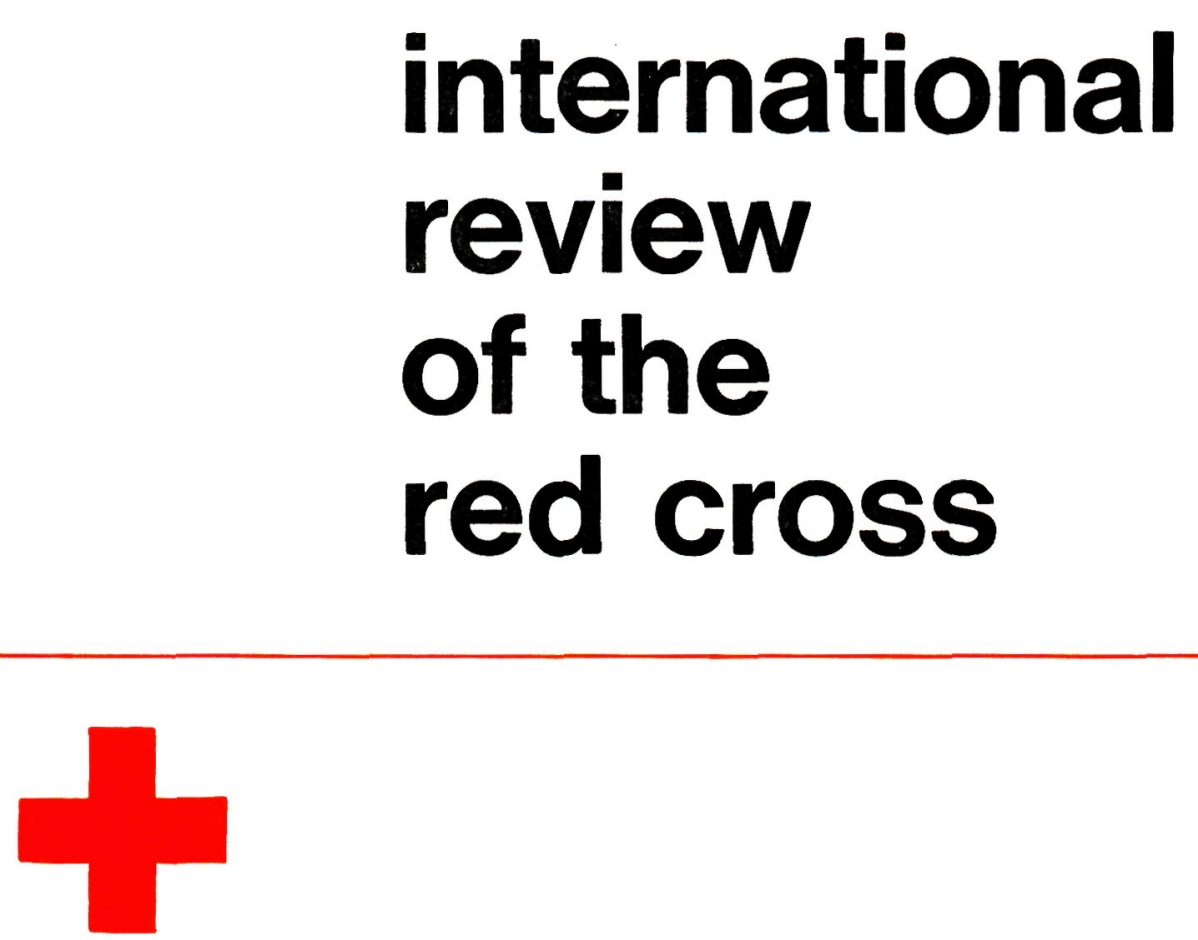

INTER ARMA CARITAS

GENEVA

INTERNATIONAL COMMITTEE OF THE RED CROSS FOUNDED IN 1863 


\section{INTERNATIONAL COMMITTEE OF THE RED CROSS}

Mr. ALEXANDRE HAY, Lawyer, former Director-General of the Swiss National Bank, President (member since 1975)

Mr. JEAN PICTET, Doctor of Laws, Chairman of the Legal Commission, Director of the Henry Dunant Institute, Associate Professor at the University of Geneva, Vice-President (1967)

Mr. HARALD HUBER, Doctor of Laws, Federal Court Judge, Vice-President (1969)

Mrs. DENISE BINDSCHEDLER-ROBERT, Doctor of Laws, Professor at the Graduate Institute of International Studies, Geneva, Judge at the European Court of Human Rights (1967)

Mr. MARCEL A. NAVILLE, Master of Arts, ICRC President from 1969 to 1973 (1967)

Mr. JACQUES F. DE ROUGEMONT, Doctor of Medicine (1967)

Mr. ROGER GALLOPIN, Doctor of Laws, former ICRC Director-General and former President of the Executive Council (1967)

Mr. VICTOR H. UMBRICHT, Doctor of Laws, Managing Director (1970)

Mr. GILBERT ETIENNE, Professor at the Graduate Institute of International Studies and at the Institut d'études du développement, Geneva (1973)

Mr. ULRICH MIDDENDORP, Doctor of Medicine, head of surgical department of the Cantonal Hospital, Winterthur (1973)

Mrs. MARION BOVÉE-ROTHENBACH, Master of Social Work (University of Michigan) Reader at the Ecole des Sciences sociales et politiques of the University of Lausanne (1973)

Mr. HANS PETER TSCHUDI, Doctor of Laws, former Swiss Federal Councillor (1973)

Mr. HENRY HUGUENIN, Bank Manager (1974)

Mr. GOTTFRIED DE SMIT, Managing Director (1974)

Mr. JAKOB BURCKHARDT, Doctor of Laws, Minister Plenipotentiary, Chairman of the Council of Federal Polytechnic Schools (1975)

Mr. THOMAS FLEINER, Master of Laws, Professor at the University of Fribourg (1975)

Mr. HERBERT LUTTHY, Doctor of Philosophy, Professor of History at the University of Basle (1975)

Mr. RICHARD PESTALOZZI, Doctor of Laws, Special Assistant to the President (1977)

Honorary members: Miss LUCIE ODIER, Honorary Vice-President;

Messrs. HANS BACHMANN,

GUILLAUME BORDIER,

Mrs. MARGUERITE GAUTIER-VAN BERCHEM,

Messrs. ADOLPHE GRAEDEL, ÉDOUARD DE HALLER, ERIC MARTIN,

RODOLFO OLGIATI, MAX PETITPIERRE, PAUL RUEGGER,

DIETRICH SCHINDLER, FRÉDÉRIC SIORDET, ALFREDO VANNOTTI.

\section{EXECUTIVE COUNCIL}

Mr. ALEXANDRE HAY, President

Mr. VICTOR H. UMBRICHT, Vice-President

Mr. RICHARD PESTALOZZI

Mrs. DENISE BINDSCHEDLER-ROBERT

Mr. THOMAS FLEINER

Mr. JEAN PICTET 


\section{INTERNATIONAL REVIEW OF THE RED CROSS}

AUGUST - SEPTEMBER - No. 197-198

Special double issue

PROTOCOLS ADDITIONAL

TO THE GENEVA CONVENTIONS

OF 12 AUGUST 1949

RESOLUTIONS OF THE

DIPLOMATIC CONFERENCE

EXTRACTS FROM THE FINAL ACT

OF THE

DIPLOMATIC CONFERENCE 


\section{REVUE INTERNATIONALE}

DE LA CROIX-ROUGE

\section{REVISTA INTERNACIONAL} DE LA CRUZ ROJA

\section{EXTRACTS FROM THE REVIEW}

GERMAN

\section{INTERNATIONAL REVIEW OF THE RED CROSS}

The French and Spanish editions, also issued every month, may be obtained at the same price.

Verbreitung des Genfer Abkommen - Hohe Auszeichnung des Niederländischen Roten Kreuzes für den Direktor des Internationalen Suchdienstes - Liste des Vertragsstaaten der Genfer Abkommen vom 12. August 1949.

The International Review is published each month by the International Committee of the Red Cross

17, avenue de la Paix, 1211 Geneva, Switzerland Postal Cheque No. 12 - 1767.

Annual subscription: Sw. Fr. 30.- (\$12.-)

Single copy Sw. Fr. 3.- (\$1.-)

EDITOR: Michel TESTUZ

The International Committee of the Red Cross assumes responsibility only for material over its own signature. 
In this issue we give the official texts of the Protocols additional to the Geneva Conventions of 12 August 1949, as adopted by the Diplomatic Conference on the Reaffirmation and Development of International Humanitarian Law applicable in Armed Conflicts. Also given are extracts from the Final Act and the texts of Conference resolutions.

The representatives of the many States participating in the Conference signed the Final Act, on 10 June 1977, by way of authentification. The two Protocols hammered out by the four sessions of the Conference from 1974 to 1977 were annexed to the Final Act.

These legal instruments prepared by the Diplomatic Conference are deposited with the Swiss Confederation. They will be open to signature for a period of twelve months starting six months after the signing of the Final Act. They shall have the force of international law six months after two instruments of ratification or accession have been deposited.

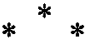

In view of the length of these texts, International Review of the Red Cross is publishing them in the form of a double issue for August and September 1977. It is felt that in view of the importance of these documents, eagerly awaited, readers will consider the Review justified in departing from its normal regularity of publication. 


\section{CONTENTS}

\section{PROTOCOL I}

\section{PART I}

\section{GENERAL PROVISIONS}

Article 1 - General principles and scope of application 4

Article 2 - Definitions . . . . . . . . . . . . . 4

Article 3 - Beginning and end of application . . . 5

Article 4 - Legal status of the Parties to the conflict . 5

Article 5 - Appointment of Protecting Powers and of their substitute . . . . . . . . . . . . 6

Article 6 - Qualified persons . . . . . . . . . 7

Article 7 - Meetings . . . . . . . . . . . . . . . 8

\section{PART II}

WOUNDED, SICK AND SHIPWRECKED

SECTION I - GENERAL PROTECTION . . . . . . . 8

Article 8-Terminology . . . . . . . . . . . . . 8

Article 9 - Field of application . . . . . . . . . . 10

Article 10 - Protection and care . . . . . . . . . 11

Article 11 - Protection of persons . . . . . . . . . 11

Article 12 - Protection of medical units . . . . . . . 12

Article 13 - Discontinuance of protection of civilian medical units . . . . . . . . 13 
Article 14 - Limitations on requisition of civilian medical units

Article $15-$ Protection of civilian medical and religious personnel . . . . . . . . . . . . . . . 14

Article $16-$ General protection of medical duties . . . 15

Article $17 \quad$ - Role of the civilian population and of aid societies . . . . . . . . . . . . 15

Article 18 - Identification . . . . . . . . . . . . 16

Article $19-$ Neutral and other States not Parties to the conflict . . . . . . . . . . . . . . . . 17

Article 20 - Prohibition of reprisals . . . . . . . 17

SECTION II - MEDICAL TRANSPORTATION . . . . 17

Article 21 - Medical vehicles . . . . . . . . . . . . 17

Article 22 - Hospitals ships and coastal rescue craft . . 17

Article 23 - Other medical ships and craft . . . . . . 18

Article 24 - Protection of medical aircraft . . . . . . 19

Article 25 - Medical aircraft in areas not controlled by an adverse Party . . . . . . . . . . 20

Article 26 - Medical aircraft in contact or similar zones 20

Article 27 - Medical aircraft in areas controlled by an adverse Party . . . . . . . . . . . . . 20

Article 28 - Restrictions on operations of medical aircraft . . . . . . . . . . . . . . . . 21

Article 29 - Notifications and agreements concerning medical aircraft . . . . . . . . . . . . 21

Article 30 - Landing and inspection of medical aircraft 22

Article 31 - Neutral or other States not Parties to the conflict . . . . . . . . . . . . . . . 23

SECTION III - MISSING AND DEAD PERSONS . . . 25

Article 32 - General principle . . . . . . . . 25

Article 33 - Missing persons . . . . . . . . . . . 25

Article 34 - Remains of deceased . . . . . . . . . 26 


\section{PART III}

\section{METHODS AND MEANS OF WARFARE COMBATANT AND PRISONER-OF-WAR STATUS}

SECTION I - METHODS AND MEANS OF WARFARE . 27

Article 35 - Basic rules . . . . . . . . . . . . 27

Article 36 - New weapons . . . . . . . . . . . . 28

Article $37 \quad$ - Prohibition of perfidy . . . . . . . . . 28

Article 38 - Recognized emblems . . . . . . . . . 28

Article $39 \quad$ - Emblems of nationality . . . . . . . . . . 29

Article 40 - Quarter . . . . . . . . . . . . . . . 29

Article 41 - Safeguard of an enemy hors de combat . . 29

Article 42 - Occupants of aircraft . . . . . . . . . 30

SECTION II - COMBATANT AND PRISONER-OF-WAR STATUS . . . . . . . . . 30

Article 43 - Armed forces . . . . . . . . . . 30

Article 44 - Combatants and prisoners of war . . . . 31

Article 45 - Protection of persons who have taken part in hostilities . . . . . . . . . . 32

Article $46-$ Spies . . . . . . . . . . . . . . . 33

Article 47 - Mercenaries . . . . . . . . . . 34

\section{PART IV}

\section{CIVILIAN POPULATION}

SECTION I - GENERAL PROTECTION AGAINST EFFECTS OF HOSTILITIES . . . . . . . . . . . . . . 34

CHAPTER I - BASIC RULE AND FIELD OF APPLICATION . . . . . . . . . . 34

Article 48 - Basic rule . . . . . . . . . . . . 34

Article 49 - Definition of attacks and scope of application . . . . . . . . . . 35 
CHAPTER II - CIVILIANS AND CIVILIAN POPULATION

Article 50 - Definition of civilians and civilian population . . . . . . . . . . . 35

Article $51 \quad$ - Protection of the civilian population . . . 36

CHAPTER III - CIVILIAN OBJECTS . . . . . . . 37

Article 52 - General protection of civilian objects . . . 37

Article $53 \quad--$ Protection of cultural objects and of places of worship . . . . . . . . . . . . . . 37

Article $54 \quad-$ Protection of objects indispensable to the survival of the civilian population . . . . 38

Article 55 - Protection of the natural environment . . 38

Article 56 - Protection of works and installations containing dangerous forces . . . . . . . 39

CHAPTER IV - PRECAUTIONARY MEASURES . . . . 40

Article $57 \quad$ - Precautions in attack . . . . . . . . . . 40

Article 58 - Precautions against the effects of attacks . 42

CHAPTER V L LOCALITIES AND ZONES UNDER SPECIAL PROTECTION . . . . . . . . . . . . . 42

Article 59 - Non-defended localities . . . . . . . 42

Article 60 - Demilitarized zones . . . . . . . . . . 43

CHAPTER VI-CIVIL DEFENCE . . . . . . . . . 45

Article 61 - Definitions and scope . . . . . . . . 45

Article 62 - General protection . . . . . . . . . . . 46

Article 63 - Civil defence in occupied territories . . . 47

Article 64 - Civilian civil defence organizations of neutral or other States not Parties to the conflict and international co-ordinating organizations . . . . . . . . . . . . 47

Article $65 \quad$ - Cessation of protection . . . . . . . . . 48

Article 66 - Identification . . . . . . . . . . . . 49

Article 67 - Members of the armed forces and military units assigned to civil defence organizations 
SECTION II - RELIEF IN FAVOUR OF THE CIVILIAN POPULATION . . . . . . . . . 51

Article 68 - Field of application . . . . . . . . . . 51

Article $69-$ Basic needs in occupied territories . . . . 52

Article $70-$ Relief actions . . . . . . . . . . 52

Article 71 - Personnel participating in relief actions . 53

SECTION III - TREATMENT OF PERSONS IN THE POWER OF A PARTY TO THE CONFLICT 54

CHAPTER I - FIELD OF APPLICATION AND PROTECTION OF PERSONS AND OBJECTS . . . 54

Article $72 \quad$ - Field of application . . . . . . . . 54

Article $73 \quad-$ Refugees and stateless persons . . . . . 54

Article $74 \quad$ - Reunion of dispersed families . . . . . . 54

Article 75 - Fundamental guarantees . . . . . . . . 54

CHAPTER II-MEASURES IN FAVOUR OF WOMEN AND CHILDREN . . . . . . . . 57

Article 76 - Protection of women . . . . . . . . 57

Article 77 - Protection of children . . . . . . . 58

Article $78 \quad$ - Evacuation of children . . . . . . . . . 58

CHAPTER III - JOURNALISTS . . . . . . . . . . 60

Article 79 - Measures of protection for journalists . . 60

\section{PART V}

EXECUTION OF THE CONVENTIONS AND OF THIS PROTOCOL

SECTION I - GENERAL PROVISIONS . . . . . . 61

Article $80-$ Measures for execution . . . . . . . . 61

Article 81 - Activities of the Red Cross and other humanitarian organizations ...... 61 
Article 82 - Legal advisers in armed forces . . . . 62

Article 83 - Dissemination . . . . . . . . . 62

Article $84 \quad$ - Rules of application . . . . . . . . 62

SECTION II - REPRESSION OF BREACHES OF THE CONVENTIONS AND OF THIS PROTOCOL . . . . . . . . . . . 63

Article $85-$ Repression of breaches of this Protocol . . 63

Article 86 - Failure to act . . . . . . . . 65

Article 87 - Duty of commanders . . . . . . 65

Article 88 - Mutual assistance in criminal matters . . 66

Article 89 - Co-operation . . . . . . . . . . 66

Article 90 - International Fact-Finding Commission . 66

Article $91 \quad$ - Responsibility . . . . . . . . . . 69

PART VI

FINAL PROVISIONS

Article $92 \quad$ - Signature . . . . . . . . . . . 69

Article $93 \quad$ - Ratification . . . . . . . . . 70

Article 94 - Accession . . . . . . . . . 70

Article $95 \quad$ - Entry into force . . . . . . . . . . 70

Article 96 - Treaty relations upon entry into force of this Protocol . . . . . . . . . 70

Article 97 - Amendment . . . . . . . 71

Article $98 \quad-$ Revision of Annex I . . . . . . . . . 71

Article $99-$ Denunciation . . . . . . . . . 72

Article 100 - Notifications . . . . . . . . 73

Article $101-$ Registration ....... . . . . 73

Article $102-$ Authentic texts . . . . . . . . . . 73 


\section{ANNEX I \\ REGULATIONS CONCERNING IDENTIFICATION}

CHAPTER I - IDENTITY CARDS . . . . . . . .

Article 1 - Identity card for permanent civilian medical and religious personnel . . . . . . . . 74

Article 2 - Identity card for temporary civilian medical and religious personnel ..... . 75

CHAPTER II - THE DISTINCTIVE EMBLEM . . . . 77

Article $3 \quad$ - Shape and nature . . . . . . . . . . 77

Article 4 - Use . . . . . . . . . . . . 77

CHAPTER III - DISTINCTIVE SIGNALS . . . . . 78

Article 5 - Optional use . . . . . . . . . . . 78

Article 6 - Light signal . . . . . . . . . . . 78

Article 7 - Radio signal . . . . . . . . . 79

Article 8 - Electronic identification . . . . . . . 79

CHAPTER IV - COMMUNICATIONS. . . . . . . 80

Article 9 - Radiocommunications . . . . . . 80

Article 10 - Use of international codes . . . . . . 80

Article 11 - Other means of communication . . . . 81

Article $12-$ Flight plans . . . . . . . . . . . . 80

Article 13 - Signals and procedures for the interception of medical aircraft . . . . . . . 81

CHAPTER V-CIVIL DEFENCE . . . . . . . . 81

Article $14 \quad$ - Identity card . . . . . . . . . . . . 81

Article $15-$ International distinctive sign . . . . . 83

CHAPTER VI - WORKS AND INSTALLATIONS CONTAINING DANGEROUS FORCES . . . 84

Article 16 - International special sign . . . . . . 84 
ANNEX II

\section{IDENTITY CARD FOR JOURNALISTS \\ ON DANGEROUS PROFESSIONAL MISSIONS}

IDENTITY CARD . . . . . . . . . . . 86

\section{PROTOCOL II}

PREAMBLE

\section{PART I}

SCOPE OF THIS PROTOCOL

Article 1 - Material field of application . . . . . . 90

Article $2 \quad-$ Personal field of application . . . . . . 90

Article 3 - Non-intervention . . . . . . . . . . . 91

\section{PART II \\ HUMANE TREATMENT}

Article 4 - Fundamental guarantees . . . . . . . . 91

Article 5 - Persons whose liberty has been restricted . 92

Article 6 - Penal prosecutions . . . . . . . . . . . 94

\section{PART III}

WOUNDED, SICK AND SHIPWRECKED

Article $7 \quad$ - Protection and care . . . . . . . . 95

Article 8 - Search . . . . . . . . . . . . . 95

Article 9 - Protection of medical and religious personnel . . . . . . . . . . . . . . 96

Article $10-$ General protection of medical duties . . . 96

Article 11 - Protection of medical units and transports 96

Article 12 - The distinctive emblem . . . . . . . 97 


\section{PART IV}

\section{CIVILIAN POPULATION}

Article $13-$ Protection of the civilian population . . .

Article 14 - Protection of objects indispensable to the survival of the civilian population . . . .

Article 15 - Protection of works and installations containing dangerous forces . . . . . . . 97

Article 16 - Protection of cultural objects and of places of worship . . . . . . . . . . . . . . 98

Article 17 - Prohibition of forced movement of civilians ............. . . 98

Article $18-$ Relief societies and relief actions . . . . 98

\section{PART V}

\section{FINAL PROVISIONS}

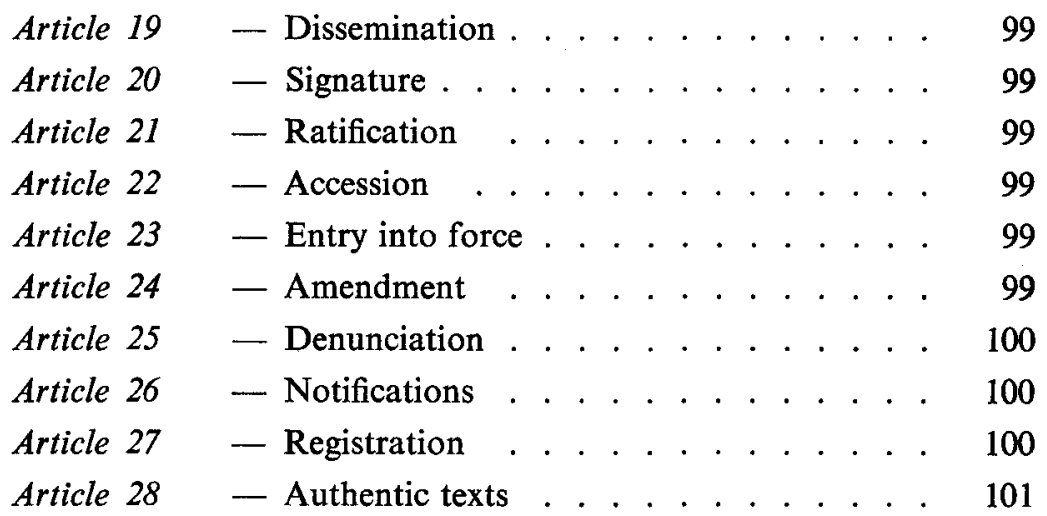




\section{RESOLUTIONS \\ ADOPTED AT THE FOURTH SESSION OF THE DIPLOMATIC CONFERENCE}

Resolution 17 - Use of certain electronic and visual means of identification by medical aircraft protected under the Geneva Conventions of 1949 and under the Protocol Additional to the Geneva Conventions of 12 August 1949, and relating to the Protection of Victims of International Armed Conflicts (Protocol I) . . . . . . . . . . . . .

Resolution 18 - Use of visual signalling for identification of medical transports protected under the Geneva Conventions of 1949 and under the Protocol Additional to the Geneva Conventions of 12 August 1949, and relating to the Protection of Victims of International Armed Conflicts (Protocol I) . . . . . .

Resolution 19 - Use of radiocommunications for announcing and identifying medical transports protected under the Geneva Conventions of 1949 and under the Protocol Additional to the Geneva Conventions of 12 August 1949, and relating to the Protection of Victims of International Armed Conflicts (Protocol I)

Resolution 20 - Protection of cultural property . . . .

Resolution 21 - Dissemination of knowledge of international humanitarian law applicable in armed conflicts ..........

Resolution 22 - Follow-up regarding prohibition or restriction of use of certain conventional weapons

Resolution 24 - Expression of gratitude to the host country 